\title{
Population structure and fruit availability of the babassu palm (Attalea speciosa Mart. ex Spreng) in human- dominated landscapes of the Northeast Region of Brazil
}

\author{
Juliana Loureiro Almeida Campos ${ }^{\star *}$, Ulysses Paulino Albuquerque', Nivaldo Peroni²and Elcida de Lima Araújo ${ }^{3}$
}

Received: July 22, 2016

Accepted: March 29, 2017

\begin{abstract}
We studied the population structure and fruit availability of the babassu palm, Attalea speciosa, in three humandominated landscapes located near a rural community in the region of Araripe, in the Northeast Region of Brazil, that were under intense fruit harvest. Fifty 10 x 10 m plots were randomly established in each of the three landscapes, and all individuals of $A$. speciosa within the plots were classified as seedlings, juveniles or adults, with the height of all adult individuals being measured. An additional 20 individuals were marked in each landscape, and the number of total bunches, fruits per bunch and bunches per palm tree were recorded. The populations of $A$. speciosa in the three landscapes exhibited an inverted J-shape plot, but pasture and shifting cultivation possessed a significantly higher number of individuals, seedlings and adults than the seasonal semideciduous forest, plus they possessed a greater seedling/adult ratio. Shifting cultivation was found to be favorable for fructification. The present study found that shifting cultivation and pastures are landscape practices that can contribute to the rapid expansion and establishment of A. speciosa, which can become a dominant species in the region of Araripe.
\end{abstract}

Keywords: extractivism, harvest, landscape management, non-timber forest products, population ecology

\section{Introduction}

The harvest of non-timber forest products (NTFPs) is an appealing alternative to unsustainable extraction of natural resources because it is considered to have a low impact on plant communities and enables the development of local human populations along with biodiversity conservation (Ticktin 2004; Soldati \& Albuquerque 2010). Nonetheless, some studies have shown that the population structure and yield of species that have products harvested can be affected by these practices (Pulido \& Caballero 2006; Brokamp et al. 2014). Studies have demonstrated that extractivism can change recruitment of populations of NTFP-producing plants (Gaoue \& Ticktin 2007; Feitosa et al. 2014; Varghese et al. 2015), thus limiting availability (Arnold \& Ruiz-Perez 2001; Ticktin 2004; Pulido \& Caballero 2006). Over time, this decreased availability affects the conservation of biological activities and socio-environmental dynamics of each location, and may even change local cultural practices. Since the harvest of NTFPs is not necessarily sustainable, more research is needed to better understand the potential consequences of this practice for species with a significant history of harvest.

The increase in problems caused by harvest activities indicates that studies on the abundance, survival, growth

\footnotetext{
${ }^{1}$ Laboratório de Ecologia e Evolução de Sistemas Socioecológicos, Departamento de Botânica, Centro de Biociências, Universidade Federal de Pernambuco, Cidade Universitária, 50670- 901, Recife, PE, Brazil

${ }^{2}$ Departamento de Ecologia e Zoologia, Universidade Federal de Santa Catarina, Campus Reitor João David Ferreira Lima, s/n - Trindade, 88040-900, Florianópolis, SC, Brazil

${ }^{3}$ Laboratório de Ecologia Vegetal de Ecossistemas Nordestinos, Departamento de Biologia, Universidade Federal Rural de Pernambuco, Av. Dom Manoel de Medeiros s/n, Dois Irmãos, 52171-900, Recife, PE, Brazil

* Corresponding author: loureiroju@hotmail.com
} 
rate, potential yield and regenerative capacity of species which are harvested are urgently needed (Hall \& Bawa 1993; Ticktin 2004). For example, fruit harvested by humans can change the rate of recruitment of new individuals into the population, decreasing population viability and the availability of animal food, thus inducing changes to trophic networks that can affect other species of the community (Hall \& Bawa 1993). Furthermore, the structure of exploited populations must be evaluated with consideration of historical land use and management practices, such as the establishment of pastures, cultivation shifts, forest management and fire use (Lykke 1998; Shanley et al. 2002; Alexiades \& Shanley 2004; Pulido \& Caballero 2006), because these factors can influence the responses of populations to extractive practices (Oostermeijer et al. 1994; Souza 2007; Giroldo \& Scariot 2015).

Palm trees are among the target species for extraction of NTFPs, and are used by human populations in several regions of the world for subsistence and trade (Balick 1984; Ticktin 2004; Pulido \& Caballero 2006). However, depending on the species, the effects of different land-use practices can be positive or negative for the exploited palm tree population. For example, Pulido \& Caballero (2006) showed that when land undergoes shifting cultivation, the quality and quantity of leaves of the palm tree Sabal yapa decrease. In contrast, agricultural and pastural land use practices have been beneficial for the palm tree Astrocaryum tucuma, and have resulted in increases in their population size (Schroth et al. 2004). Deforestation does not seem to affect the development of the palm Ceroxylon quindiuense, because individuals of this species are spared by logging and because of the resilience of their large juvenile rosettes (Sanín et al. 2013).

In Brazil, local human populations heavily harvest the fruits and leaves of babassu palm, Attalea speciosa, for human and animal food, as well as for artisanal, construction, medicinal, cosmetic and commercial purposes, mainly in the North and Northeast regions of the country (Balick 1984; Rufino et al. 2008; Souza et al. 2011; González-Pérez et al. 2012; Campos et al. 2015; Araújo et al. 2016). This species can occur isolated in forests or in areas used for agriculture or pasture, and is considered a pioneer and dominant species in anthropically altered areas because it is an efficient colonizer (Ribeiro \& Walter 1998; Mitja \& Ferraz 2001). Assuming that land management systems can influence population structure and fruit yield of A. speciosa, the current study aimed to evaluate the effect of three forms of landscape management (pasture, shifting cultivation and seasonal semideciduous forest) on: a) the total number of individuals in, and the life stage distribution of, A. speciosa populations; $b$ ) the seedling/adult ratio and height class distribution of A. speciosa populations; and c) the bunch and fruit yield of $A$. speciosa populations. The populations evaluated experience intense fruit harvest. Because babassu palms tend to form large populations in open areas (Ribeiro
\& Walter 1998; Mitja \& Ferraz 2001), a significantly higher number of individuals, higher seedling/adult ratio, higher number of seedling and juvenile plants and a higher rate of bunch and fruit production per individual were expected in areas managed for pasture and shifting cultivation than in seasonal semideciduous forest. Furthermore, we expected a seedling/adult ratio $>1$ for the three landscape units, with pasture and shifting cultivation being higher than that of seasonal semideciduous forest.

\section{Materials and methods}

\section{Study species}

The babassu palm (Attalea speciosa Mart. ex Spreng) is widely distributed, occupying the entire North Region of Brazil, the sates of Maranhão, Piauí and Mato Grosso, and isolated areas in the Northeast Region (states of Ceará, Pernambuco and Alagoas), as well as Bolivia, Guianas and Suriname (Lorenzi 2010). Some authors affirm that in primary vegetation, the babassu palm occurs in low densities of adult individuals, but with a high density of seedlings (Anderson \& May 1985; Peters et al. 1989; Anderson et al. 1991), while after anthropic deforestation it emerges as a dominant species (Pinheiro 2004). According to Mitja \& Ferraz (2001), the success of this species in disturbed areas is due to the negative geotropism of the terminal bud in early development, which offers protection against fire, a common practice in disturbed areas. Babassu palm has a straight, single and cylindrical stem of $10-30 \mathrm{~m}$ in height and $30-60 \mathrm{~cm}$ in diameter. The inflorescenses are large, and male and female infloreescences occur on the same plant (Lorenzi 2010). Each fruit bunch contains 200-600 elliptic to oblong fruits (Orwa et al. 2009).

\section{Study area}

The study was performed at the Araripe Environmental Protection Area (EPA - Araripe). The EPA - Araripe is a sustainable-use conservation unit with approximately 1.063 million hectares in the states of Ceará, Piauí and Pernambuco, Brazil, and comprises several private properties. Within EPA - Araripe, there is a second sustainable use conservation unit called the National Forest of Araripe-Apodi (Floresta Nacional do Araripe-Apodi - FLONA Araripe), which was established by Decree-Law No. 9,226/46. The FLONA Araripe encompasses the municipalities Crato, Barbalha, Jardim and Santana do Cariri, and possesses an area of approximately $38,262,326$ hectares (Ibama 2004) with the following vegetation formations: seasonal semideciduous forest, 'Cerradão' (savanna woodland), 'Cerrado sensu stricto' (Brazilian savanna) and 'carrasco' (xerophytic shrubby vegetation) (Ribeiro-Silva et al. 2012).

The climate of the region is characterized as tropical wet and dry or savanna climate (Aw) (Köppen et al. 1948). 
It experiences temperatures from 14 to $26^{\circ} \mathrm{C}$ (Lima 1983), five to seven dry months (Cavalcanti \& Lopes 1994) and an annual rainfall greater than $1,000 \mathrm{~mm}$ in the upper slopes of the plateau (850 to 1,000 m.a.s.l.; MMA 2007). The soils of the Araripe Plateau are deep and well-drained yellow and red-yellow Latosols (Oxisols) (Ibama 2004).

Within EPA - Araripe, the rural community of Macaúba Ranch was selected for study because this community has a strong history of extractivism of babassu palm (Ibama 2004). There are approximately 250 families in the community, and babassu fruits are primarily collected for the production of oil from seeds and for making crafts, while the bark and seed are sold for coal and soap production, respectively (Campos et al. 2015). Other sources of income in Macaúba include agriculture and extractivism of "pequi" (Caryocar coriaceum Wittm.) (Sousa Junior et al. 2013). Babassu palm is considered a resource of high commercial importance for the residents of this community, and subsistence use is uncommon. Babassu has been used with increasing frequency since 1990, when the Macaúba Rural Association was created, which promoted increased babassu oil production by providing machinery (Campos et al. 2015). At Macaúba, A. speciosa is mainly present in pastures, open fields, agricultural lands and seasonal semideciduous forest fragments (Campos et al. 2015). There is no record of intentional planting of trees of A. speciosa by the residents of Macaúba Ranch.

The present study was approved by the Biodiversity Authorization and Information System (Sistema de Autorização e Informação em Biodiversidade - SISBIO) (process number 31857-1) and the National Research Ethics Committee (Comitê Nacional de Ética em Pesquisa - CONEP) (process number CAAE 01457712.7.0000.5207).

\section{Data collection sites}

In order to identify areas subjected to different types of land use where A. speciosa fruit extraction is performed, informal conversations were held with extractivists of the community. They were asked to indicate areas in EPA Araripe where palm trees are exploited, and three landscape units within private properties of extractivists that live in Macaúba Ranch were identified (Fig. 1).

\section{Population structure}

The geographical coordinates of the three landscape units were recorded and used in the preparation of three maps. The maps were divided into grid cells/plots of $10 \times 10$ meters, and 50 plots were randomly selected in each map to study the A. speciosa population. The randomly selected plots were established in the field with the aid of a Global Positioning System (GPS) for a total of 150 plots and 1.5 hectares of sampled area.
In each plot, all individuals of $A$. speciosa were numbered and classified according to ontogenetic stage following an adaptation of the classification of Souza et al. (2000), as follows: a) seedling - every specimen with leaflets not completely separated; b) juvenile - every specimen with fully expanded leaves, but no trace of previous reproduction; and c) adult - every specimen with traces of previous reproduction or presence of fruits and/or flowers. Height (measured from ground level to the point of leaf sheath insertion of the lower leaf for specimens with woody stems, or measured from the ground to the tip of the largest leaf for seedlings and juvenile plants without woody stems) was measured for all specimens using a clinometer for juveniles and adults, and a metric tape for seedlings.

\section{Fruit production}

In each of the three landscape units, 20 adult specimens were marked and numbered, for a total of 60 specimens. All bunches with ripe fruit were cut from each individual and the number of fruit per bunch was recorded. The same individuals were monitored for 12 months in order to estimate the number of bunches produced and the number of fruits per bunch, which corresponded to five visits to each unit.

\section{Data analysis}

We considered each plot a sample unit and tested the data for normality using Shapiro-Wilk Test, which revealed it was not normal. The total number of $A$. speciosa individuals and the number of individuals of each ontogenetic stage found in each landscape unit were compared using KruskalWallis test. The seedling/adult ratio was calculated for the three populations of $A$. specios $a$, with a ratio $>1$ indicating good recruitment and a ratio $<1$ indicating low recruitment (Mwavu \& Witkowski 2009); it should be noted that in the present work we opted to use the term "regeneration" rather than "recruitment". The Chi-square goodness-of-fit test was used to assess significant differences in the seedling/adult ratio among the three populations. Height values were divided among classes of 0.5-meter-intervals, following an adaptation of Monteiro \& Fisch (2005). Differences in height class distribution among the three landscape units were assessed using Kolmogorov-Smirnov test. To identify gaps in height class distribution, we tested the fit of a negative exponential distribution $\mathrm{y}=\mathrm{ae}-\mathrm{bx}$ across populations. In this equation, " $y$ " represents the frequency of individuals in each size class, " $\mathrm{x}$ " is the midpoint of the size classes, "a" is the intercept, " $b$ " is the slope of the curve (which represents the mortality rate of the populations) and "e" is the natural logarithmic base (Hett \& Loucks 1976). The number of individuals in each height class and the value of the midpoint of each size class were logarithmitically 


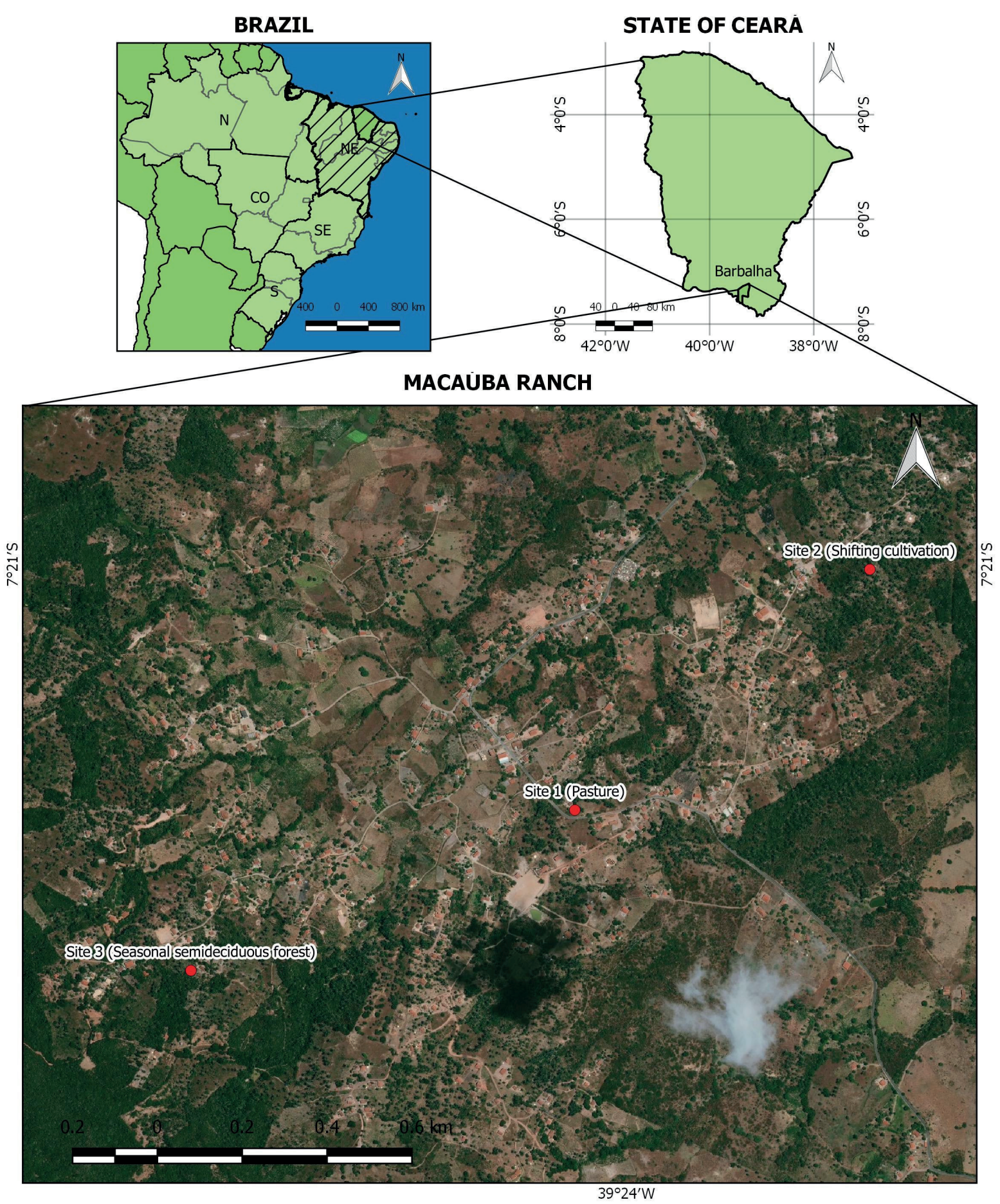

Figure 1. Study Area (Macaúba Ranch, Ceará State, Northeastern Brazil) and landscape units where plots were established for the study of population structure of Attalea speciosa Mart. ex Spreng. Landscape Unit 1: Pasture - 07²1'19.0”S, 39²4’04.3”W (675 m.a.s.l.). This area is used as cattle pasture and has history of fire use, with the last fire event being about 15 years prior to the current study. It comprises an area of 1.54 ha and, according to the land owner, frequent cutting of $A$. speciosa has been performed to avoid competition between this palm species and other plant species that serve as food for cattle. Landscape Unit 2: Shifting cultivation $07^{\circ} 21^{\prime} 00.4^{\prime \prime S}, 39^{\circ} 23^{\prime} 41.6^{\prime \prime} \mathrm{W}$ (630 m.a.s.l.). In this area, extractivists grow pigeon pea (Cajanus cajan (L.) Huth) and faba bean (Vicia faba L.), with the last planting being performed five years before the current study. This area comprises an area of 2.09 ha and has a history of fire use, with the last fire event being about one year prior to the current study. Landscape Unit 3: Seasonal semideciduous forest $-07^{\circ} 21^{\prime} 31.0^{\prime \prime}$ S, $39^{\circ} 24^{\prime} 33.8^{\prime \prime} \mathrm{W}$ (759 m.a.s.l.). This area corresponds to a small fragment of 2.12 ha that contains several clearings. The extractivists reported that fire was used in this fragment two years prior to the current study to prevent excessive growth of the forest for use as pasture. 
transformed. Thus, simple regression analyses were made for each of the three populations studied. In this analysis, the number of individuals in each height class was considered the response variable and the midpoint value was considered the explanatory variable. The slopes of the curves (b) were analyzed to verify the perpetuation of the tendency of populations, which was verified by a negatively accentuated slope (Condit et al. 1998).

Differences in the number of bunches and fruits produced by individuals of $A$. speciosa in each landscape unit were assessed using the Kruskal-Wallis test. All statistical analyses were performed using BioEstat 5.0 software (Ayres et al. 2007) and $\mathrm{R}$ version 3.2 ( $\mathrm{R}$ Development Core Team 2007).

\section{Results}

\section{Population structure}

In total, 3,637 individuals of $A$. speciosa were recorded in all three landscape units, with 1,691, 1,495 and 451 specimens being recorded in the pasture, shifting cultivation and seasonal semideciduous forest, respectively. The total number of individuals observed in each of the three landscape units was significantly different $(\mathrm{H}=38.2057$; $\mathrm{p}<0.0001)$ and differences were observed between pasture and seasonal semideciduous forest $(\mathrm{z}=4.6184 ; \mathrm{p}<0.05)$ as between shifting cultivation and seasonal semideciduous forest $(z=5.8637 ; p<0.05)$, but not between pasture and shifting cultivation $(\mathrm{z}=1.2452 ; \mathrm{p}>0.05)$.

Table 1 shows the number of specimens in each ontogenetic stage for the three landscape units. The shifting cultivation unit exhibited the greatest difference among ontogenetic stages of $A$. speciosa individuals, with $94.4 \%$ seedlings and only $5.6 \%$ juveniles and adults. Significant differences were found among the three landscape units for seedlings $(H=44.76 ; p<0.0001)$, and differences were found between pasture and seasonal semideciduous forest $(\mathrm{z}=4.8716 ; \mathrm{p}<0.05)$ as well as between shifting cultivation and seasonal semideciduous forest $(z=6.4046 ; p<0.05)$, but not between pasture and shifting cultivation $(\mathrm{z}=1.533$; $\mathrm{p}>0.05)$. The number of juveniles did not differ among these three units $(H=3.1259 ; \mathrm{p}=0.2095)$. The number of adults differed significantly among the three landscape units $(H=6.4183 ; p<0.05)$. There were no significant differences between pasture and shifting cultivation $(z=1.7413$; p $>0.05$ ), and between shifting cultivation and seasonal semideciduous forest $(z=0.6986 ; p>0.05)$, but there was a significant difference between pasture and seasonal semideciduous forest $(z=2.4398 ; \mathrm{p}<0.05)$, with fewer adults being recorded in seasonal semideciduous forest (Tab. 1).

As expected, A. speciosa exhibited a greater number of seedlings even under fruit harvest, since the seedling/ adult ratio was greater than 1 in the three units: shifting cultivation (48.7), pasture (31.5) and seasonal semideciduous forest (16.0). Significant differences in the seedling/adult ratio were observed between the pasture and seasonal semideciduous forest $\left(\chi^{2}=4.34 ; \mathrm{p}<0.05\right)$ and between the shifting cultivation and seasonal semideciduous forest $\left(\chi^{2}=15.43 ; p<0.01\right)$. However, there was no significant difference in the seedling/adult ratio between pasture and shifting cultivation $\left(\chi^{2}=3.30 ; p=0.07\right)$, showing that these units have a significantly higher number of seedlings than seasonal semideciduous forest.

Regarding height class distribution, significant differences in the number of specimens at each height class were observed between pasture and shifting cultivation $(D=0.0388 ; p=0.05)$, pasture and seasonal semideciduous forest $(D=0.526 ; p<0.0001)$ and shifting cultivation and seasonal semideciduous forest $(D=0.5251 ; p<0.0001)$. A greater number of specimens were in the first three height classes ( 0 to 1.5 meters) than in all the other classes in pasture and shifting cultivation (Fig. 2). In seasonal semideciduous forest, the intermediate classes, which correspond to juveniles ( 2 to 5 meters), possessed a greater number of individuals than pasture and shifting cultivation. The $A$. speciosa populations in the three landscape units showed an inverted J-shape plot: pasture $(\mathrm{F}=26.5258 ; \mathrm{p}=0.0009$; $\left.\mathrm{R}^{2}=0.7185\right)$; shifting cultivation $(\mathrm{F}=30.9554 ; \mathrm{p}=0.0006$; $\left.\mathrm{R}^{2}=0.7497\right)$; seasonal semideciduous forest $(\mathrm{F}=15.1939$; $\mathrm{p}=0.0039 ; \mathrm{R}^{2}=0.5867$ ). The coefficients of regression (b) showed negative values for the three populations $(-1.9986$, -1.8289 and -0.7293 , respectively), indicating that the three populations are in good conservation condition, with the first two units being in a better condition than the third.

\section{Fruit production}

No significant differences were observed in the number of bunches produced per individual $(H=3.841 ; p=0.1465)$, or in the average number of fruits produced per bunch, among the landscape units $(\mathrm{H}=4.2915 ; \mathrm{p}=0.117)$ (Tab. 2). However, significant differences were observed in the average number of fruits produced per individual among the three landscape units $(H=6.9169 ; \mathrm{p}<0.05)$, with significant differences between shifting cultivation and seasonal semideciduous forest $(z=2.4762 ; p<0.05)$, but not between pasture and shifting cultivation $(z=0.4708$; $p>0.05$ ), or between pasture and seasonal semideciduous forest $(z=2.0054 ; p>0.05)$ (Tab. 2).

\section{Discussion}

The results of the present study showed that the pasture and shifting cultivation landscape units possessed better establishment of $A$. speciosa populations than the seasonal semideciduous forest, since we found: (a) a significantly greater number of specimens in pasture 
Table 1. Number of individuals per ontogenetic stage of Attalea speciosa Mart. ex Spreng located in three landscape units near the rural community Macaúba Ranch, municipality of Barbalha, state of Ceará, Brazil.

\begin{tabular}{|c|c|c|c|c|}
\hline \multicolumn{5}{|c|}{ Ontogenetic stages } \\
\hline Study area & Seedling & Juvenile & Adults & Total \\
\hline $1-$ Pasture & $1476(87.3 \%)$ & $168(9.9 \%)$ & $47(2.8 \%)$ & 1691 \\
\hline $2-$ Shifting cultivation & $1411(94.4 \%)$ & $55(3.7 \%)$ & $29(1.9 \%)$ & 1495 \\
\hline $3-$ Seasonal semideciduous forest & $305(67.7 \%)$ & $127(28.2 \%)$ & $19(4.1 \%)$ & 451 \\
\hline
\end{tabular}

Table 2. Fruit yield and average yield per individual of Attalea speciosa Mart. ex Spreng located in three landscape units near the rural community Macaúba Ranch, municipality of Barbalha, state of Ceará, Brazil, for a period of 12 months. Variation amplitude values in parenthesis.

\begin{tabular}{|c|c|c|c|c|}
\hline \multicolumn{5}{|c|}{ Yield } \\
\hline Study area & Total of bunches & $\begin{array}{l}\text { Bunches/ } \\
\text { specimen }\end{array}$ & $\begin{array}{c}\text { Fruits/ } \\
\text { bunch }\end{array}$ & $\begin{array}{c}\text { Fruits/ } \\
\text { specimen }\end{array}$ \\
\hline 1- Pasture & 37 & $1.85(1-4)$ & $274.06(133-442)$ & $494.8(220-1.170)$ \\
\hline 2- Shifting cultivation & 40 & $2.00(1-4)$ & $278.18(54-545)$ & $554.8(159-1.191)$ \\
\hline 3-Seasonal semideciduous forest & 29 & $1.45(1-2)$ & $230.95(101-445)$ & $349.2(101-770)$ \\
\hline
\end{tabular}

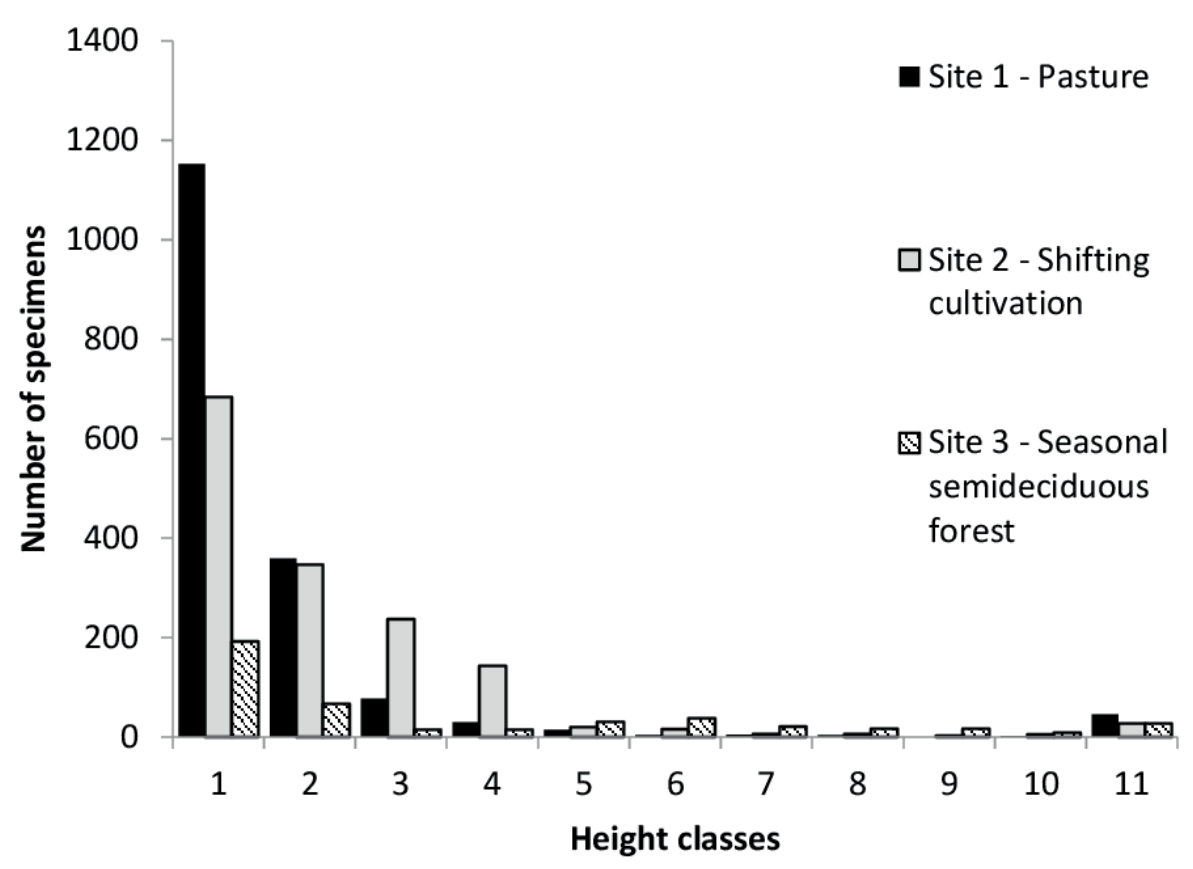

Figure 2. Height class distribution of individuals of Attalea speciosa Mart. ex Spreng located in three landscape units near the Macaúba Ranch, municipality of Barbalha, state of Ceará, Brazil. Height classes: 1 (0-0.5 m); 2 (0.51- 1 m); 3 (1.01-1.5 m); 4 (1.51-2 m); 5 (2.01-2.50 m); 6 (2.51-3 cm); 7 (3.01-3.5 m); 8 (3.51-4 m); 9 (4.01-4.50 m); 10 (4.51-5 m); and 11 (>5.0 m).

and shifting cultivation; (b) a significantly greater number of seedlings and adults in pasture and shifting cultivation; (c) a significantly higher seedling/adult ratio in pasture and shifting cultivation; and (d) a greater average number of fruit produced per specimen in shifting cultivation. However, this statement must be taken with some caution since the study did not evaluate replicates of the three landscape units.

The establishment of $A$. speciosa populations in shifting cultivation can be related to a higher rate of fructification, since individuals in shifting cultivation were found to produce a greater average number of fruits in comparison to seasonal semideciduous forest. Increased establishment in pasture and shifting cultivation also seems to be related to light incidence, based on previous studies with $A$. speciosa. Some palm trees are light-demanding species and thus are more abundant in open areas with greater penetration of high levels of light through the understory (Kahn \& Castro 1985). This was true for A. speciosa in the present study, since pasture and shifting cultivation were the most open landscape units. Besides that, babassu palm is a successful competitor during the initial stages of succession (Ribeiro \& Walter 1998; Mitja \& Ferraz 2001; Pinheiro 2004). For example, in the region of Cocais 
in the state of Maranhão, Brazil, this palm emerged as a dominant species after the deforestation of primary forests for the establishment of shifting cultivation and pasture (Pinheiro 2004). The success of these palms is greatest in pastures with more recent encroachment, as was observed by Rocha et al. (2016). These authors found that A. speciosa dominates this kind of environment between the first and third year after pasture encroachment, but become less abundant toward the end of a chronosequence of 36 years post-encroachment (Rocha et al. 2016).

On the other hand, an experiment conducted by Anderson et al. (1991) showed that germination of babassu was significantly higher among shaded fruits than in fruits exposed to the sun, indicating that germination is least successful in disturbed sites. So then, why did this species possess greater numbers of individuals in pasture and shifting cultivation, than in semideciduous forest, in the present study? It is likely that $A$. speciosa germinates well in seasonal semideciduous forest, but does not complete its life cycle in this kind of environment as well as in illuminated environments, such as pasture and shifting cultivation. Besides that, this species exhibits cryptogeal germination, a kind of germination that causes their stems to arise from below ground, which contributes substantially to babassu's capacity to dominate the landscape and recover from disturbance (Anderson et al. 1991). Thus, it is likely that light decreases the rate of seed germination in shifting cultivation, but the greater number of fruits produced in this unit seems to compensate for this decrease. In seasonal semideciduous forest, seed germination is high (Anderson et al. 1991), but the absence of light probably decreases the development of seeds to seedlings in this environment.

Regarding to establishment of adult individuals, pasture and shifting cultivation exhibited greater success with more adult individuals than seasonal semideciduous forest. In the present study, we found significant differences in the seedling/adult ratio between shifting cultivation and seasonal semideciduous forest, with it being greater in the former. This result, associated with the fact that adult individuals in shifting cultivation produced on average a greater number of fruits in comparison to seasonal semideciduous forest, indicates that the characteristics of this unit contributes to the better establishment of adult individuals.

The seedling/adult ratio greater than 1 in all landscape units demonstrates that regeneration of A. speciosa populations in the three areas is good, even under pressure from fruit harvest. The lack of significant differences in this ratio between pasture and shifting cultivation indicates a similarity in the regeneration of the two units, most likely because of the lower number of seedlings in the seasonal semideciduous forest.

The distribution of individuals among height classes resulted in an inverted J-shaped plot (Hall \& Bawa 1993) for each of the three landscape units, showing a greater number of individuals in the lower height classes than in the high height classes. Most likely, the few adult specimens in seasonal semideciduous forest still offer a sufficient number of seeds to maintain population viability despite the intense fruit harvest occurring in the region. However, we found a significantly greater number of individuals with intermediate height in the seasonal semideciduous forest than in the pasture and shifting cultivation units. Although a lower number of seedlings were found in seasonal semideciduous forest than in pasture and shifting cultivation, it is likely that the mortality rate of this stage in this kind of environment is lower than in the other units, so the probability to reach the juvenile stage is greater.

The fact that individuals in shifting cultivation produced on average a greater number of fruits than those located in semideciduous seasonal forest confirms another hypothesis of the current study. Lima (2011) noted that infructescence production by $A$. speciosa was high in both grazing and oldgrowth Amazon forest, a finding that was related to the great number of individuals in these two units. We suggest that the onset of reproduction of A. speciosa (Barot et al. 2005) could explain our findings. According to Barot et al. (2005), A. speciosa reproduction is size dependent, and light is the limiting factor. Thus, since shifting cultivation is more open than seasonal semideciduous forest, and thus has greater luminosity, the individuals in this unit do not have to grow as much to start reproduction. In contrast, forests have low luminosity, so individuals of $A$. speciosa need to reach the canopy to get the necessary light to acquire and store the energy needed to trigger reproduction, and so they begin reproduction at larger sizes (Barot et al. 2005). In our study, we found fewer adults in semideciduous forest than in shifting cultivation, and these individuals probably have not started reproduction, thus explaining the low average fruit production in this unit.

It is probable that the high rate of fruit production in shifting cultivation also represents an evolutionary strategy to compensate for the low rate of seed germination in this environment. Since seed germination in disturbed areas is low due to high light intensity (Anderson et al. 1991), A. speciosa individuals in this kind of environment have to produce more fruits to compensate for the low proportion of seeds that reach germination.

In conclusion, pasture and shifting cultivation landscape units exhibited the best establishment of $A$. speciosa because they had a greater number of individuals, a greater number of seedlings and adults and the largest seedling/adult ratio. However, juveniles exhibited good establishment in seasonal semideciduous forest, which was likely due to the low mortality rate of seedlings in this environment. Shifting cultivation was more favorable for fructification than semideciduous seasonal forest, probably because of the size dependence of $A$. speciosa reproduction. We conclude that shifting cultivation and pasture units contribute to the rapid expansion and establishment of $A$. speciosa, which can become a dominant species in the Araripe region. 


\section{Acknowledgements}

The authors would like to thank the Fundação de Amparo a Ciência e Tecnologia de Pernambuco (FACEPE) for the scholarship granted to the first author; the Coordenação de Aperfeiçoamento de Pessoal de Nível Superior (CAPES) for the financial support granted by the National Program for Post Doctoral degree (Programa Nacional de Pós Doutorado - PNPD) (process number 23038.008230/2010-75); and the Conselho Nacional de Desenvolvimento Científico e Tecnológico (CNPq) for the scholarships awarded to the authors.

\section{References}

Alexiades M, Shanley P. 2004. Productos forestales, medios de subsistencia y conservación: estudios de caso sobre sistemas de manejo de productos forestales no maderables. In: Alexiades M, Shanley P. (eds.) Productos forestales, medios de subsistencia y conservación: estudios de caso sobre sistemas de manejo de productos forestales no maderables. Vol. 3-America Latina. Jakarta, Centro para la Investigación Forestal Internacional. p. 1-24.

Anderson AB, May P. 1985. A palmeira de muitas vidas. Ciência Hoje 4: 58-64. Anderson AB, May P, Balick MJ. 1991. The natural history of babassu. In: Anderson AB, May P, Balick MJ. (eds.) The subsidy from nature: palm forests, peasantry, and development on an Amazon frontier. New York, Columbia University Press. p. 35-96.

Araújo FR, González-Pérez SE, Lopes MA, Viégas IJM. 2016. Ethnobotany of babassu palm (Attalea speciosa Mart.) in the Tucuruí Lake Protected Areas Mosaic-eastern Amazon. Acta Botanica Brasilica 30: 193-204.

Arnold JEM, Ruiz-Perez M. 2001. Can non-timber forest products match tropical forest conservation and development objectives? Ecological Economics 39: 437-447.

Ayres M, Ayres Jr M, Ayres DL, Santos AAS. 2007. BioEstat: aplicações estatísticas nas áreas das ciências bio-médicas. Belém, Sociedade Civil Mamirauá-Belém (MCT-CNPq).

Balick MJ. 1984. Ethnobotany of Palms in the Neotropics. Advances on Economic Botany 1: 9-23.

Barot S, Mitja D, Miranda IS, Meija GD, Grimaldi M. 2005. Reproductive plasticity in an Amazonian palm. Evolutionary Ecology Research 7: 1-15.

Brokamp G, Pedersen HB, Montúfar R, Jácome J, Weigend M, Balslev H. 2014. Productivity and management of Phytelephas aequatorialis (Arecaceae) in Ecuador. Annals of applied biology 164: 257-269.

Campos JLA, Silva TLL, Albuquerque UP, Araújo EL. 2015. Knowledge, use and management of the babassu palm (Attalea speciosa Mart. ex Spreng) in the Araripe Region (Northeastern Brazil). Economic Botany 69: 240-250.

Cavalcanti AC, Lopes OF. 1994. Condições edafo-climáticas da Chapada do Araripe e viabilidade de produção sustentável de culturas. Brasília, Embrapa-SPI.

Condit R, Sukumar R, Hubbell SP, Foster RB. 1998. Predicting population trends from size distributions: a direct test in a tropical tree community. The American Naturalist 152: 495-509.

Feitosa IS, Albuquerque UP, Monteiro JM. 2014. Knowledge and extractivism of Stryphnodendron rotundifolium Mart. in a local community of the Brazilian Savanna, Northeastern Brazil. Journal of Ethnobiology and Ethnomedicine 10: 1. doi: 10.1186/1746-4269-10-64.

Gaoue OG, Ticktin T. 2007. Patterns of harvesting foliage and bark from the multipurpose tree Khaya senegalensis in Benin: variation across ecological regions and its impacts on population structure. Biological Conservation 137: 424-436.

Giroldo AB, Scariot A. 2015. Land use and management affects the demography and conservation of an intensively harvested Cerrado fruit tree species. Biological Conservation 191: 150-158.
González-Pérez SE, Coelho-Ferreira M, Robert P, Garces CLL. 2012. Conhecimento e usos do babaçu (Attalea speciosa Mart. e Attalea eichleri (Drude) A. J. Hend.) entre os Mebêngôkre-Kayapó da Terra Indígena Las Casas, estado do Pará, Brasil. Acta Botanica Brasilica 26: 295-308.

Hall B, Bawa K. 1993. Methods to assess the impact of extraction of nontimber tropical forest products on plant population. Economic Botany 47: 234-247.

Hett JM, Loucks OL. 1976. Age structure models of Balsam Fir and Eastern Hemlock. Journal of Ecology 64: 1029-1044.

Ibama - Instituto Brasileiro do Meio Ambiente e dos Recursos Naturais Renováveis. 2004. Plano de manejo da Floresta Nacional do Araripe. Brasília, Ibama

Kahn F, Castro A. 1985. The palm community in a forest of central Amazonia, Brazil. Biotropica 20: 266- 269.

Köppen W. 1948. Climatologia: con un estudio de los climas de la tierra. Tlalpan, Fondo de Cultura Económica.

Lima JMT. 2011. Ecology of native oil-producing palms and their potential for biofuel production in southwestern Amazonia. PhD Thesis, University of Florida, Gainesville.

Lima MF. 1983. Mapeamento e demarcação da Floresta Nacional do Araripe. Fortaleza, IBDF/FCPC/UFC.

Lorenzi H. 2010. Flora Brasileira: Arecaceae (Palmeiras). 1st. edn. Nova Odessa, Instituto Plantarum.

Lykke AM. 1998. Assessment of species composition change in savanna vegetation by means of woody plants size class distributions and local information. Biodiversity and Conservation 7: 1261-1275.

Mitja D, Ferraz I. 2001. Establishment of Babassu in pastures in Pará, Brazil. Palms 45: 138-147.

MMA - Ministério do Meio Ambiente. 2007. Região do Araripe: diagnóstico florestal (Pernambuco). Brasília, Secretaria de Ciências, Tecnologia e Meio Ambiente.

Monteiro EA, Fisch STV. 2005. Estrutura e padrão espacial das populações de Bactris setosa Mart e B. hatschbachii Noblick ex A. Hend (Arecaceae) em um gradiente altitudinal, Ubatuba (SP). Biota Neotropica 5: 111-117.

Mwavu EN, Witkowski ETF. 2009. Population structure and regeneration of multiple-use tree species in a semi-deciduous African tropical rainforest: implications for primate conservation. Forest Ecology and Management 258: 840-849.

Oostermeijer JGB, Vant' Veer R, Den Nijs JCM. 1994. Population structure of the rare, long-lived perennial Gentiana pneumonanthe in relation to vegetation and management in the Netherlands. Journal of Applied Ecology 31: 428-438.

Orwa C, Mutua A, Kindt R, Jamnadass R, Simons A. 2009. Agroforestree database: a tree reference and selection guide version 4.0. http://www. worldagroforestry.org/treedb/. 05 Jun. 2016.

Peters CM, Balick MJ, Kahn F, Anderson AB. 1989. Oligarchic forests of economic plants in Amazonia: utilization and conservation of an important tropical resource. Conservation Biology 3: 41-349.

Pinheiro CUB. 2004. A palmeira babaçu (Orbignya phalerata Martius) e sua exploração na região dos cocais, Maranhão, nordeste do Brasil. In: Alexiades M, Shanley P. (eds.) Productos forestales, medios de subsistencia y conservación: estudios de caso sobre sistemas de manejo de productos forestales no maderables. Vol. 3 - America Latina. Jakarta, Centro para la Investigación Forestal Internacional. p. 163-180.

Pulido MT, Caballero J. 2006. The Impact of shifting agriculture on the availability of non-timber forest products: the example of Sabal yapa in the Maya Lowlands of Mexico. Forest Ecology and Management 222: 399-409.

R Development Core Team. 2007. A language and environment for statistical computing. R Foundation for Statistical Computing. Vienna, Austria. www.R-project.org.

Ribeiro JF, Walter BMT. 1998. Fitofisionomias do bioma Cerrado. In: Sano SM, Almeida SP. (eds.) Cerrado: ambiente e flora. Planaltina, Embrapa. p. 87-166.

Ribeiro-Silva S, Medeiros MB, Gomes BM, Seixas ENC, Silva MAP. 2012. Angiosperms from the Araripe National Forest, Ceará, Brazil. Checklist 8: 744-751. 


\section{Population structure and fruit availability of the babassu palm (Attalea speciosa Mart. ex Spreng) in human-dominated landscapes of the Northeast Region of Brazil}

Rocha GPE, Vieira DLM, Simon MF. 2016. Fast natural regeneration in abandoned pastures in southern Amazonia. Forest Ecology and Management 370: 93-101.

Rufino MUL, Costa JTM, Silva VA, Andrade LHC. 2008. Conhecimento e uso do ouricuri (Syagrus coronata) e do babaçu (Orbignya phalerata) em Buíque, PE, Brasil. Acta Botanica Brasilica 22: 1141-1149.

Sanín MJ, Anthelme F, Pintaud JC, Galeano G, Bernal R. 2013. Juvenile resilience and adult longevity explain residual populations of the Andean wax palm Ceroxylon quindiuense after deforestation. PLoS ONE 8, e74139. doi:10.1371/journal.pone.0074139.

Schroth G, Mota MSS, Lopes R, Freitas AF. 2004. Extractive use, Management and in situ domestication of a weedy palm, Astrocaryum tucuma, in the central Amazon. Forest Ecology and Management 202: 161-179.

Shanley P, Luz L, Swingland R. 2002. The faint promise of a distant market: a survey of Belem's trade in non-timber forest products. Biodiversity and Conservation 11: 615-636.

Soldati GT, Albuquerque UP. 2010. Produtos Florestais Não-Madeireiros: uma visão geral. In: Albuquerque UP, Hanazaki N. (eds.) Árvores de valor e o valor das árvores: pontos de conexão. Recife, Nuppea. p. 17-59.
Sousa Junior JR, Albuquerque UP, Peroni N. 2013. Traditional knowledge and management of Caryocar coriaceum Wittm. (Pequi) in the Brazilian Savanna, Northeastern Brazil. Economic Botany 67: 225-233.

Souza AF. 2007. Ecological interpretation of multiple population size structures in trees: the case of Araucaria angustifolia in South America. Austral Ecology 32: 524-533.

Souza AF, Martins FR, Matos DMS. 2000. Detecting ontogenetic stages of the palm Attalea humilis in fragments of the Brazilian Atlantic forest. Canadian Journal of Botany 78: 1227- 1237.

Souza MHSL, Monteiro CA, Figueredo PMS, Nascimento FRF, Guerra, RNM. 2011. Ethnopharmacological use of babassu (Orbignya phalerata Mart) in communities of babassu nut breakers in Maranhão, Brazil. Journal of Ethnopharmacology 133: 1-5.

Ticktin T. 2004. The ecological implications of harvesting non-timber forest products. Journal of Applied Ecology 41: 11-21.

Varghese A, Ticktin T, Mandle L, Nath S. 2015. Assessing the effects of multiple stressors on the recruitment of fruit harvested trees in a tropical dry forest, Western Ghats, India. PLoS ONE 10, e0119634. doi:10.1371/ journal.pone.0119634. 